\title{
STATT EINES VORWORTS
}

"Ulrich Middeldorf has had a genius for selfless devotion not only to learning in the abstract, but personally and concretely to students of many ages and many nationalities. His career has joined research administration to university teaching and museums of art. It has linked the North of Europe, the Mediterranean and the Middle West of the New World. To him the Atlantic has been no barrier but instead a wide pathway for friendship. In latter years his class-room has become the whole city of Florence; and the long, freely-ranging conversations in his study at the Kunsthistorisches Institut, so generously given of his own time, have become more prized than any course of lectures. «

Aus dem Beitrag von Charles Seymour, Jr. (Seite 93). 